\title{
Students' Satisfaction Using E-Learning as a Supplementary Tool
}

\author{
https://doi.org/10.3991/ijet.v16i15.23925
}

\author{
Ai Chin Thoo, See Pheng Hang $\left({ }^{\varpi}\right)$, Yoke Lai Lee, Liat Choon Tan \\ Universiti Teknologi Malaysia, Johor, Malaysia \\ sphang@utm.my
}

\begin{abstract}
E-learning is useful to help students gaining digital and data literacy during their studies particularly in the era of Industrial Revolution 4.0 (IR 4.0). E-learning which is characterized by time and place flexibility should be utilized as a tool for self-learning. In Universiti Teknologi Malaysia (UTM), elearning plays an important role as a supplementary tool for effective web-based learning. The purpose of this study is to examine what are the factors that drive students' satisfaction in e-learning. A total of 194 samples were collected from undergraduate students in UTM using quantitative method. Purposive sampling technique was used to select the respondents. Statistical Package for the Social Sciences (SPSS) was utilized for data analysis. The findings showed that delivery method and content have a positive and significant relationship with satisfaction of using e-learning. However, system operations has no impact on students' satisfaction in e-learning. In conclusion, the finding of this study is expected to provide an effective teaching model for general education schools.
\end{abstract}

Keywords-E-learning, pedagogical, satisfaction

\section{$1 \quad$ Introduction}

In Malaysia tertiary education, e-learning has been actively implemented for decades to strengthen public education. The e-learning management system is recognized as an essential online learning tool for both in classroom and outside classroom learning. Online e-learning provides students a flexible and efficient pathway to access course materials, to communicate with instructor, interact with classmates, participate in different online activities and perform online assessment. Furthermore, the e-learning facilitates students to learn a subject individually and collaboratively. The continuity of e-learning implementation is believed to increase the effectiveness of teaching and learning for adult education. Now, e-learning is playing a significant role during COVID-19 pandemic since the teaching and learning activities in higher educations are fully online right after the first Movement Control Order on 18 March 2020.

E-learning can be defined as using Information and Communication Technologies (ICTs) to gain new knowledge. The use of learning strategies and technological resources has increased the efficiency of teaching and learning progressions [1]. The UTM's e-learning centre was established since 1998 and it was known as virtual learning 
in the early implementation. Currently, the e-learning or electronic learning is implemented in UTM using web-based learning approaches and is associated with face-toface classroom learning in most of the subjects. The technology based learning is feasible to be applied in the era of technology using computers and smart phones. This approach can be known as "mixed mode" application where degree of online learning is increased whereas face-to-face teaching is reduced [2]. The benefits of using e-learning in universities include 24-hour information access, up-to-date course materials, self-paced learning and cost effectiveness [3].

Although the online learning could lower per-student costs, nevertheless the high investment cost has been paid by the university to improve the infrastructure of online learning platform as well as Internet services. Undeniably, students are able to access useful sources of information and knowledge in their studies. Also, e-learning could provide flexibility to educators and learners to participate in various educational activities such as online quiz or test, assignment submission, discussion, material preparation, evaluation and many more when compared to traditional classroom approach.

In fact, there are challenges with regard to the acceptance and adoption of e-learning, particularly in developing countries such as Nigeria, Pakistan and Ghana. The challenges include fear of isolation [4], skill limitation of instructors, lack of proper infrastructure, no computer, cultural beliefs and English translation to local languages [5], as well as low computer skills, limited access to Internet services, lack of awareness, unaffordable cost of implementation and unreliable platform [6].

Besides acknowledging the challenges, it is important to analyse student satisfaction that may improve e-learning practices and student retention. By designing a satisfying online curricula, satisfied students are likely to stay in the program. A number of studies explore the satisfaction with online learning. Convenience was found to trigger student satisfaction and lack of interaction is strongly related to dissatisfaction [7]. As proven, eLearning courses should provide trustworthy learning experiences and assignments with collaborative efforts among students that meet students' needs and interest, which in turn will improve the learning environment, students' social presence and satisfaction in eLearning courses [8]. On the other hand, a study compared online program and on-ground courses in terms of content and delivery, and found that students attending online program were satisfied with the courses [9]. Evidently, there are many factors that affect student satisfactions with online learning. For instances, more adaptive and personalized e-learning systems [10], online technical support, assessment options, grading system and training workshops [11], understandability, enjoyment, enthusiasm, illustration and fostering attention [12], platform availability [13] as well as e-learning service quality including instructor and course materials quality, system quality, and administrative and support service quality [14].

E-learning is useful to help students gaining digital and data literacy during their studies particularly in the era of Industrial Revolution 4.0 (IR 4.0). E-learning which is characterized by time and place flexibility should be utilized as a tool for self-learning. As such, it is important to investigate what is the most important characteristic that drives effective online teaching as perceived by the students. In this study, the satisfactory level of undergraduate students in the current practice of UTM's e-learning implementation is examined through a survey on e-learning strategies and management. 
Paper-Students' Satisfaction Using E-Learning as a Supplementary Tool

\section{$2 \quad$ Literature review}

Previous studies have used different theories and models to examine students' satisfaction in online learning environment. In this study, theory of a psychological contract is used to predict students' satisfaction in E-learning.

\subsection{Psychological contracts}

The theory of psychological contracts was developed by Argyris in 1960 for workplace purpose [15]. The contracts requires no written agreements and two parties maintain implicit understanding using a mutual relations. Therefore, the contracts are very subjective with different prospects and obligations that have significant implications on employee satisfaction and performance [16]. There are six components of workplace psychological contracts: joint agreement, choice of voluntary, contract makers, unfinished, planning for losses from unsuccessful contract, and reciprocal relationships between employer and employee [17] with clear expectations [18].

The theory of a psychological contract can be applied in educational environment. A study found that there is a mutual exchange between instructors and student. The interaction revolves around both parties expectations and the contract is predominately asymmetric. The instructor plays the role as employer with higher power to control student performance and educational resources including recommendation letter, grade, advice on projects and assignments [19]. On the other hand, students as role of employees would form expectations such as course content and delivery, facilities, faculty, student/academic development, involvement, feedback, support and learning opportunities [20].

Using this theory of psychological contracts, both students and instructors/faculty mutually agree on a large number of contracts with little to no explicit communication about the rights and duties of both sides due to the contracts are temporary and informal. However, the contracts regulates the satisfactions challenges for both parties if their expectations are not met. For examples, the expectations include class expects of each other, class expects of instructor and instructor expects of class [21]. Thus far, several studies have used psychological contract to increase student satisfaction [21, 22, 23]. Obviously, the psychological contract is an important pedagogic tool in education process. The nature of psychological contract is used to elucidate the expectations of the students and provides insight to instructors to improve their teaching strategies based on students' expectation. As a result, the instructors would receive higher course evaluations due to increased classroom dynamics and student satisfaction. This means the contract is identified before the class and the satisfaction is formed after the class [23].

\subsection{Research framework}

As indicated in Figure 1, there are three hypotheses were developed for the relationships between delivery method, content, system operations and students' satisfaction in using e-learning. 


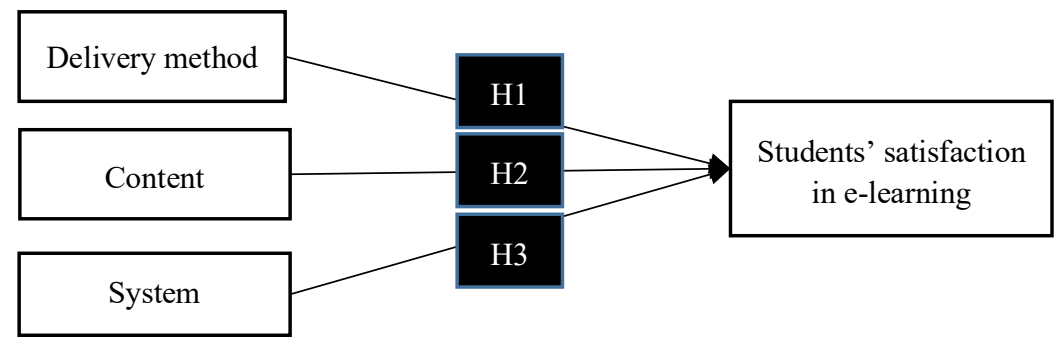

Fig. 1. Research Framework

\subsection{Student satisfaction}

Satisfaction is known as an important measurement indicator for product or service quality [24]. When a product's perceived performance or the requirements of the product meets a buyer's desires, satisfaction is achieved [25]. From the perspective of elearning, satisfaction is measured in terms of pedagogical facets and information systems. As proven, teaching effectiveness is one of the measures of teaching quality [26]. Effective teaching is classically defined as presentation, facilitation and regulation [27]. However, some studies investigated students' evaluations of educational quality to include learning/value, organization, enthusiasm, individual rapport, group interaction, breadth of coverage, exams/grades, assignments and workloads [28].

Recent studies found that community relationships [29], preparation, attraction, participation, interaction, consolidation and post-course support [30] are the important characteristics that lead to effective teaching. On the other hand, information systems are closely related to the e-learning context. The classic measures of computer user satisfaction include content, accuracy, format, ease of use and timeliness [31]. A study developed four factors to assess e-learner satisfaction such as learning community, learner interface, content and personalization [26]. In eLearning courses, students' satisfaction is examined in terms of worth of time, enjoyment, preference, looking forward, excitement and stimulating [8]. A recent study investigated student satisfaction on online education platform using learning needs, use feeling and attractiveness during the COVID-19 pandemic [13].

A review of the literature shows that researchers measure factors affecting satisfaction of students in online learning differently. Pekrun's control-value theory of achievement emotions was used to investigate students' emotions and satisfaction with online learning in a blended course [12]. The study found that increased levels of enjoyment, enthusiasm, illustration, understandability and fostering attention lead to high student satisfaction. In addition, applying DeLone and Mclean success model to Kano twodimensional model was utilized to measure the students' satisfaction level [32]. A study found that student satisfaction with distance learning is closely related to rules and regulation, web portal for distance learning, material quality and interaction with teachers and peers [33]. Additionally, agency, engaged learning and assessment are important predictors for online learning [23]. 
Results of previous studies indicated that interactivity, learning materials quality and perceived ease of use of the e-learning play vital role in influencing students' satisfaction and success in online learning environment. The learning environment should be conducive to include instructor support, interaction and collaboration, autonomy, authentic learning, personal relevance and active learning [8]. Therefore, this study aims to investigate three factors for satisfaction in e-learning: delivery method, content and system operations. The delivery method encompasses personal skills in organizing and grading, interpersonal skills such as presentation, advising and group interaction [34]. The content includes timeliness [35] and learner interface content [26]. Lastly, system operations cover ease of use, accuracy [35] and personalization [26].

\subsection{Delivery methods}

Delivery methods are the ways of instructors convey instructions or course content to students for learning purpose [36]. There are three methods of course delivery-faceto-face, interactive television (iTV) and purely online delivery [37]. The face-to-face is a kind of traditional educational delivery system, in which a professor gives lectures to students in a classroom and the students listen to take notes [38]. Then, education delivery mechanisms evolve to include iTV and online delivery that challenge the traditional approaches of teaching and learning.

Now, educational delivery methods become more diverse including personalized learning, e-learning, blended learning and mobile learning [36]. E-learning is one of the effective tools of online educations delivery system. Taken role as a "disruptive technology", e-learnings offer scales economies in terms of saving in time distance costs. This means e-learning allows teaching and learning at anytime and anywhere. Teachers are no longer as importers of knowledge and they serve more like facilitators for learners in the process of gaining knowledge [38].

The effectiveness of the delivery method revolves around how well the materials uploaded in e-learning by instructor is easy for students to understand, students' satisfactions in terms of the format of material provided and ways of activities such as quizzes and exercises in e-learning improve the learning as well as fun and knowledge they gain with the e-learning system [34]. Delivery in online learning environment is defined as response time from instructor, relevancy of activities to the goal of the course, participation in discussion questions, online communication with peers, as well as supportiveness and responsiveness of instructor to questions [9].

E-learning methods include asynchronous and synchronous [39, 40]. Asynchronous e-learning is a self-paced where students can download any learning documents at anywhere, anytime, and just-in-time via log on to a virtual learning environment. Also, students might send private messages to teachers or peers for knowledge enhancement. Asynchronous e-learning involves cognitive participation to increase reflection and ability to process information [39].

On the other hand, synchronous learning is instructor-led and supported by media such as video conferencing, web conferencing and virtual works [41]. Synchronous learning maintains classroom culture and allows remote students to interact with in- 
structors in online face-to-face classes. It can reduce the impact of isolation by providing flexibility for students to ask and answer questions in real time. Synchronous learning environments stimulates personal participation in terms of motivation, arousal and convergence [39]. However, synchronous learning should be integrated into asynchronous tools to ensure effective learning.

Now, the Covid-19 pandemic has pushed many varsities to move their classes online. They use various asynchronous modes such as video, screen recording, collaborative team work and gamification to allow lecturers upload learning materials in online channels so that students can access anytime. The learning takes place without real-time interaction with lecturers. Also, synchronous learning is used for teaching and learning activities that happens in real time via live learning session including Webex, Zoom, Google Meet and Skype for Business, discussion, forum and chat using WhatsApp, Telegram and e-learning platform as well as game-based learning through Kahoot and Socrative [42].

Undeniably, COVID-19 is a global challenge for many varsities to ensure the effectiveness of learning and assessment are being carried out accordingly. Study found that effective delivery method such as opportunities to collaborate with other students could increase student satisfaction [23]. Based on the above discussion, the following hypothesis is proposed:

H1: Delivery method is positively and significantly related to students' satisfaction in e-learning.

\subsection{Content}

Learning includes the effective transition of content knowledge from instructors to students. Content can be defined as the resources teachers use to deliver instruction. The resources include knowledge and information that teachers use to support students to learn in a particular content area such as marketing and engineering. Content or teaching materials can be delivered in numerous forms and sizes with a common goal to support student learning. The examples of teaching materials consist of books, magazines, short stories, dictionaries, and encyclopedias, academic journals, worksheets, essays, web sites, documents, apps as well as media elements such as illustrations, diagrams and textual content in order for learners to discover new knowledge. Online content includes goals of course are clearly stated, expectation is met, grading criteria are clearly communicated, realistic workloads, textbook supporting the learning outcomes, relevancy of other reading materials to the course objectives, and content of the video to achieve learning outcomes [9].

Therefore, accurate and high-quality content in learning material is essential to drive student success in learning. Content must provide up-to-date information and includes constant changes to safeguard that quality and suitability of the learning resources are attained [43]. Studies found that outdated learning materials could fail to meet the learning outcomes [44] and those materials with high difficulty could lead to student dispositions [45]. This means an instructor's priority should be to make learning materials updated with error free without mistakes in grammar, instruction and formula in order to achieve a productive and efficient learning experience for students. 
Numerous stages involved in module development process and found out that open communication and fine-tuning quality assurance process are important to achieve quality content at the Open University Malaysia [46]. In fact, learning is not about a teacher delivers content to students, but it is more to the engagement with that content to make a learning meaningful, effective, integrated and transferable. Indeed, meaningful directed content is closely related to "student's motivation to learn and willingness to reinvest in learning" [47]. This study focuses on content provided in e-learning in terms of up-to-date, examples of the real world situation, sufficiency with additional resources and links to other web sites [34] that drives student satisfaction. According, the below hypothesis is formed:

$\mathrm{H} 2$ : Content is positively and significantly related to students' satisfaction in e-learning.

\subsection{System operations}

System operation in terms of ease of use is the degree to which a person believes that using a new technology or a system is free of effort [48]. Also, a system is easy to use when users interpret and understand about a system, as well as their ease to obtain the technology or system to perform task and less mental effort needed to operate the technology or system [49]. With the diffusion of the internet, ease of use has become an important element in internet application and information system research [50, 51]. Nowadays, most of the applications are created or designed to enable users to use the application easily. Undeniably, ease of use is recognized as key factor of the user's attitude toward new technologies [52]. In this study, the success of an e-learning system depends on its ease of use and personalization in operations and adoption from instructors and students.

Many studies investigate the ease of use in online learning. Perceived ease of use and perceived usefulness have a direct effect on the intention of using e-learning systems. This includes the e-learning should be easy to operate and flexible with clear interaction between instructor and students [53]. A study proposed the antecedents of perceived ease of use of online learning using learner self-regulatory processes and behaviours, personality differences, and external factors such as technical training and support, as well as equipment accessibility [54]. Based on a recent study, the e-learning system quality is the most important factor for e-learning student satisfaction, which in turn positively influences e-learning student loyalty [55]. Based on the above discussion, the following hypothesis is developed:

H3: System operations is positively and significantly related to students' satisfaction in e-learning.

\section{$3 \quad$ Research methodology}

\subsection{Population and sampling}

The population of the study is undergraduate students from Faculty of Science and Azman Hashim International Business School, UTM. UTM widely adopts e-learning as a supplementary source to the traditional classroom approach. This study adopted a 
non-probability sampling technique: purposive sampling technique to collect the data for more accurate results. The sample was selected based on the criteria that the students had used e-learning for content need and assessment. 200 respondents are the fair number for sample size [56]. However, 194 responses were collected due to some incomplete surveys. In this study, questionnaires items were adopted and adapted from previous study [34] and were distributed through manual based method and online submission using e-learning system in order to escalate the rate of response.

\subsection{Research instrument and measurement}

Research Instrument can be categorized into two methods which are qualitative method and quantitative method for data collection of a study. In this study, the selected research instrument for collecting, analyzing and interpreting data is quantitative method. Quantitative method deals with quantifying and evaluation variable to get the outcome. Data is analyzed using mathematical methods. Questionnaire is one of the commonly use method in survey which consists of a list of questions in open-ended or close-ended form for the respondents to provide their answer with the purpose of gathering primary data. In this study, close-ended questionnaires were distributed through online by using Google form.

The survey instrument was developed by using some existing scales from prior study [34]. The delivery method encompasses the presentation and format of material provided in e-learning is easy to understand and activities in e-learning could improve the students' learning. The measurement items for content include up-to-date course content, real world practices/examples, adequacy and additional resources and links. For system operations, the questionnaire items consist of ease-of-use, performance, interactions with other students and instructor, accessibility and design of the e-learning. The learner's satisfaction is about the overall satisfaction with the e-learning system.

\section{$4 \quad$ Data analysis and findings}

\subsection{Normality test}

Normality test is used to determine the normally distributed of a data set. As shown in Table 1, the results found that the Skewness and Kurtosis values for delivery method, content, system operations and e-learner satisfaction are less than 2 and less than 7 [57]. Thus, it concludes that in this study, the data set is normally distributed.

\subsection{Reliability test}

Reliability test is used to identify the reliability of questionnaire construct of the study which include internal consistency and reliability. The reliability and acceptability of the Cronbach Alpha value should be higher than 0.7 [58]. As indicated in Table 
2, the results found that the Cronbach's Alpha values for all variables which are delivery method, content, system operations and e-learner satisfaction are reliable and valid due to the variables values are more than 0.7 .

Table 1. Normality Test

\begin{tabular}{|l|c|c|c|c|}
\hline \multicolumn{1}{|c|}{ Variable } & Skewness & Std. Error & Kurtosis & Std. Error \\
\hline Delivery method & -1.043 & .004 & 2.680 & .175 \\
\hline Content & -1.026 & .175 & 1.742 & .347 \\
\hline System operations & -.501 & .175 & .974 & .347 \\
\hline E-learner satisfaction & -.822 & .175 & .804 & .347 \\
\hline
\end{tabular}

Table 2. Reliability Test

\begin{tabular}{|l|c|c|}
\hline \multicolumn{1}{|c|}{ Variable } & No. of Items & Cronbach's Apha \\
\hline Delivery method & 4 & .846 \\
\hline Content & 4 & .813 \\
\hline System operations & 7 & .853 \\
\hline
\end{tabular}

\subsection{Multiple regression}

The multicollinearity test is used to ensure that each of the variable tolerance value is more than 0.1 while the variance inflation factor (VIF) value are less than 10 . A multiple regression analysis was conducted to investigate the relationships between delivery method, content, system operations and e-learners' satisfaction.

No multicollinearity issue is found among all the variables due to each of the variable tolerance value is more than 0.1 while the variance inflation factor (VIF) value are less than 5 as shown in Table 3 . In addition, $\mathrm{R}^{2}$ for e-learner satisfaction achieves 0.675 , in other word, it shows that $65.6 \%$ of e-learner satisfaction is significantly explained by delivery method and content (See Table 4) since the results in Table 5 found that delivery method and content show significant and positive relationship with e-learner satisfaction as their p-value is 0.000 . Among two factors, delivery method is the strongest predictor for e-learner satisfaction as the value of beta shows 0.501 . However, system operations has no impact on students' satisfaction in e-learning.

Table 3. Multicollinearity Test

\begin{tabular}{|l|l|l|}
\hline \multicolumn{1}{|c|}{ Variable } & \multicolumn{1}{c|}{ Tolerance } & \multicolumn{1}{c|}{ VIF } \\
\hline Delivery method & 0.401 & 2.496 \\
\hline Content & 0.327 & 3.057 \\
\hline System operations & 0.330 & 3.034 \\
\hline E-learner satisfaction & 0.401 & 2.496 \\
\hline
\end{tabular}

Table 4. Model Summary

\begin{tabular}{|c|c|c|c|c|}
\hline \multicolumn{1}{|c|}{ Model } & R & R Square & Adjusted R Square & Std. Error of the Estimate \\
\hline 1 & $.813^{\mathrm{a}}$ & .661 & .656 & .430 \\
\hline
\end{tabular}

a. Predictors: (Constant), delivery method, content, system operations 
Paper-Students' Satisfaction Using E-Learning as a Supplementary Tool

Table 5. Multiple Regression

\begin{tabular}{|c|c|c|c|c|c|}
\hline \multicolumn{6}{|c|}{ Coefficients $^{a}$} \\
\hline \multirow[t]{2}{*}{ Model } & \multicolumn{2}{|c|}{ Unstandardized Coefficients } & $\begin{array}{c}\text { Standardized } \\
\text { Coefficients }\end{array}$ & \multirow[t]{2}{*}{$\mathbf{t}$} & \multirow[t]{2}{*}{ Sig. } \\
\hline & $B$ & Std. Error & Beta & & \\
\hline Constant & -.050 & .233 & & -.216 & .829 \\
\hline Delivery method & .565 & .083 & .501 & 6.811 & .000 \\
\hline Content & .378 & .081 & .312 & 4.672 & .000 \\
\hline System operations & .080 & .090 & .065 & .884 & .378 \\
\hline
\end{tabular}

a. Dependent Variable: E-learner satisfaction

\section{Conclusion}

This study investigates how satisfaction of e-learners can be achieved when e-learning is used as the supplementary tool to enhance classroom teaching in UTM. The results found that delivery method and content are essential for e-learners' satisfaction. The delivery method is the critical element for satisfaction of e-learners. The results from this study are consistent with several prior studies [23, 34].

Students prefer e-learning system with clear and concise materials being uploaded in the system by instructor. Also, the materials such as quizzes and exercises in e-learning could increase effective teaching and learning when students gain knowledge and enjoyment in the e-learning system. On the other hand, the instruction delivery method using e-learning could convey a large quantity and high quality of content to students which in turn leads to increased student satisfaction. Tech-savvy students expect elearning content to cover practical "real world" examples. This concludes that innovative teaching methods, course design and educational technology contribute to effective teaching and learning. The findings are aligned with the theory of psychological contract in which both instructors and students clarify their expectations in order to achieve greater student satisfaction. In addition, the results of this study are congruent with previous findings that content drives higher e-learners' satisfaction [46, 47].

Undeniably, e-learning technologies offer learners control over content, pace of learning, learning sequence, media and time in order for them to customize their experiences to achieve their personal learning objectives. However, e-learning operation system in UTM has no impact on learners' satisfaction. As such, it is proposed for UTM to revisit the user interface design from the student's perspective. Because friendly user interface design is critical to enhance designing learning experiences and influence a user's perception of an entire learning process.

Overall, the findings of the study are significant to higher institutions. The quality of e-learning online system can be improved by providing friendly dashboard and navigation in order to help the users to track the update of their learning materials and progress effectively. The communication platform such as online discussion can be upgraded to motivate the two-way online interactions between instructors and students during teaching and learning activities, as well as among students. Lastly, the instructors could put more efforts and creativity to make the delivery of content in e-learning to be meaningful and interesting. 
As a conclusion, this study is relevant to Industrial Revolution that focuses heavily on interconnectivity, automation, and real-time data. E-learning technology is aligned with IR 4.0 that focuses on digital technology. Students could access to real-time data and get feedback from lecturers. IR 4.0 offers a more comprehensive, interlinked, and holistic approach to education. It connects physical with digital, and allows for better collaboration and access across students and lecturers. Most importantly, IR 4.0 empowers students to better control and understand every aspect of their learning for better performance. Therefore, this study could serve as a future guide for researchers to conduct more in-depth studies including interview to validate that e-learning is one of the data-driven indications of future online education success.

\section{Acknowledgment}

The authors wish to thank the Malaysian Ministry of Education (MOE), Universiti Teknologi Malaysia (UTM) and Research Management Centre (RMC) for financial support to this work through grants funding number R.J130000.2654.17J37.

\section{$7 \quad$ References}

[1] Ngampornchai, A., \& Adams, J. (2016). Students' Acceptance and Readiness for E-learning in Northeastern Thailand. International Journal of Educational Technology in Higher Education, 13, 1, 1-13. https://doi.org/10.1186/s41239-016-0034-x

[2] Bates, T. (2001). National Strategies for E-learning in Postsecondary Education. Paris: UNESCO: International Institute for Educational Planning. http://unesdoc.unesco.org/images/0012/001262/126230e.pdf

[3] Wong, A., \& Sixl-Daniell, K. (2017). The Importance of E-learning as a Teaching and Learning Approach in Emerging Markets. International Journal of Advanced Corporate Learning, 10(1), 45-54. https://doi.org/10.3991/ijac.v10i1.6471

[4] Addah, J. (2012). Computer Literacy and E-learning: Attitudes among First Year Students in a Ghanaian Medical School. International Journal of Computer Applications, 51, 22, $21-$ 25. https://doi.org/10.5120/8343-1960

[5] Iqbal, M., \& Ahmad, M. (2010). Enhancing Quality of Education through E-Learning: The Case Study of Allama Iqbal Open University. Turkish Online Journal of Distance Education, $11,1,84-97$.

[6] Folorunso, O., Ogunseye, O. S., \& Sharma, S. K. (2006). An Exploratory Study of the Critical Factors Affecting the Acceptability of E-learning in Nigerian Universities. Information Management \& Computer Security, 14, 5, 496-505. https://doi.org/10.1108/09685220 $\underline{610717781}$

[7] Cole, M. T., Shelley, D. J., \& Swartz, L. B. (2014). Online Instruction, E-learning, and Student Satisfaction: A Three Year Study. The International Review of Research in Open and Distributed Learning, 15, 6, 111-131. https://doi.org/10.19173/irrodl.v15i6.1748

[8] Strong, R., Irby, T. L., Wynn, J. T., \& McClure, M. M. (2012). Investigating Students' Satisfaction with eLearning Courses: The Effect of Learning Environment and Social Presence. Journal of Agricultural Education, 53, 3, 98-110. https://doi.org/10.5032/jae.2012.03098

[9] Roach, V., \& Lemasters, L. (2006). Satisfaction with Online Learning: A Comparative Descriptive Study. Journal of Interactive Online Learning, 5, 3, 317-332. 
[10] Sunkara, V. M., \& Kurra, R. R. (2017). An Analysis of Learner Satisfaction and Needs on E-learning systems. International Journal of Computational Intelligence Research, 13(3), 433-444.

[11] Almusharraf, N., \& Khahro, S. (2020). Students Satisfaction with Online Learning Experiences during the COVID-19 Pandemic. International Journal of Emerging Technologies in Learning, 15, 21, 246-267. https://doi.org/10.3991/ijet.v15i21.15647

[12] Ghaderizefreh, S., \& Hoover, M. L. (2018). Student Satisfaction with Online Learning in a Blended Course. International Journal of Digital Society, 9, 3, 1393-1398. https://doi.org/10.20533/ijds.2040.2570.2018.0172

[13] Chen, T., Peng, L., Yin, X., Rong, J., Yang, J., \& Cong, G. (2020). Analysis of User Satisfaction with Online Education Platforms in China during the COVID-19 Pandemic. Healthcare, 8, 3, 200. https://doi.org/10.3390/healthcare8030200

[14] Pham, L., Limbu, Y. B., Bui, T. K., Nguyen, H. T., \& Pham, H. T. (2019). Does E-learning Service Quality Influence E-Learning Student Satisfaction and Loyalty? Evidence from Vietnam. International Journal of Educational Technology in Higher Education, 16, 1, 1-26. https://doi.org/10.1186/s41239-019-0136-3

[15] Argyris, C. (1960). Understanding Organizational Behavior. Homewood, IL: Dorsey.

[16] Bordia, S., Hobman, E. V., Restubog, S. L. D., \& Bordia, P. (2010). Advisor-Student Relationship in Business Education Project Collaborations: A Psychological Contract Perspective. Journal of Applied Social Psychology, 40, 9, 2360-2386. https://doi.org/10.1111/ j.1559-1816.2010.00662.x

[17] Rousseau, D. M. (1990). Normative Beliefs in Fund-Raising Organizations Linking Culture to Organizational Performance and Individual Responses. Group \& Organization Management, 15, 4, 448-460. https://doi.org/10.1177/105960119001500408

[18] Raja, U., Johns, G., \& Ntalianis, F. (2004). The Impact of Personality on Psychological Contracts. The Academy of Management Journal, 47, 3, 350-367. https://doi.org/ $\underline{10.5465 / 20159586}$

[19] Wade-Benzoni, K. A., Rousseau, D. M., \& Li, M. (2006). Managing Relationships across Generations of Academics: Psychological Contracts in Faculty-Doctoral Student Collaborations. International Journal of Conflict Management, 17, 1, 4-33. https://doi.org/ $\underline{10.1108 / 10444060610734154}$

[20] Spies, A. R., Wilkin, N. E., Bentley, J. P., Bouldin, A. S., Wilson, M. C., \& Holmes, E. R. (2010). Instrument to Measure Psychological Contract Violation in Pharmacy Students. American Journal of Pharmaceutical Education, 74, 6, 1-11. https://doi.org/10.5688/ aj7406107

[21] Anderson, E. S. (1987). The Psychological Contract: A Method for Increasing Student Satisfaction. Journal of Marketing Education, 9, 2, 25-29.

[22] Pratt, R. M. (2005). Class Participation in Online Learning Environments-The Role of the Psychological Contract in Determining Use of Computer Mediated Communication. $11^{\text {th }}$ Americas Conference on Information Systems (AMCIS 2005), August 11-14 2005, Omaha, Nebraska, USA, pp. 487.

[23] Dziuban, C., Moskal, P., Thompson, J., Kramer, L., DeCantis, G., \& Hermsdorfer, A. (2015). Student Satisfaction with Online Learning: Is It a Psychological Contract? Journal of Asynchronous Learning Network, 1-15. https://doi.org/10.24059/olj.v19i2.496

[24] Zeithaml, V. A., Bitner, M. J., \& Gremler, D. D. (2018). Services Marketing: Integrating Customer Focus across the Firm. McGraw-Hill Education.

[25] Kotler, P., \& Armstrong, G. (2012). Principle of Marketing: The Millennium Edition. New Jersey: Prentice Hall. 
[26] Wang, Y. S. (2003). Assessment of Learner Satisfaction with Asynchronous Electronic Learning Systems. Information \& Management, 41, 1, 75-86. https://doi.org/10.1016/s0378-7206(03)00028-4

[27] Feldman, K. A. (1976). The Superior College Teacher from the Students' View. Research in Higher Education, 5, 3, 243-288. https://doi.org/10.1007/bf00991967

[28] Marsh, H. W. (1982). SEEQ: A Reliable, Valid, and Useful Instrument for Collecting Students' Evaluations of University Teaching. British Journal of Educational Psychology, 52, 1, 77-95. https://doi.org/10.1111/j.2044-8279.1982.tb02505.x

[29] Al Barwani, T. A., Al-Ani, W. T., \& Amzat, I. H. (2012). An Effective Teaching Model for Public School Teachers in the Sultanate of Oman. Education, Business and Society: Contemporary Middle Eastern Issues, 23-46. https://doi.org/10.1108/17537981211225844

[30] Wong, B.T.-m. (2016). Factors Leading to Effective Teaching of MOOCs. Asian Association of Open Universities Journal, 11, 1, 105-118. https://doi.org/10.1108/aaouj-07-2016$\underline{0023}$

[31] Doll, W. J., Raghunathan, T. S., Lim, J. S., \& Gupta, Y. P. (1995). A Confirmatory Factor Analysis of the User Information Satisfaction Instrument. Information Systems Research, 6, 2, 177-188. https://doi.org/10.1287/isre.6.2.177

[32] Bauk, S., Šćepanović, S., \& Kopp, M. (2014). Estimating Students' Satisfaction with Web Based Learning System in Blended Learning Environment. Education Research International, 1-12. https://doi.org/10.1155/2014/731720

[33] Krsmanovic, M., Djuric, M., \& Dmitrovic, V. (2012). A Survey of Student Satisfaction with Distance Learning at Faculty of Organizational Sciences, University of Belgrade. Communications in Computer and Information Science, 248:111-117. https://doi.org/10.1007/9783-642-31800-9 12

[34] Siritongthaworn, S., \& Krairit, D. (2006). Satisfaction in E-learning: The Context of Supplementary Instruction. Campus-Wide Information Systems, 23, 2, 76-91. https://doi.org/10.1108/10650740610654465

[35] Doll, W. J., \& Torkzadeh, G. (1988). The Measurement of End-User Computing Satisfaction. MIS Quarterly, 12, 2, 259-274. https://doi.org/10.2307/248851

[36] Kahiigi, E. K., Ekenberg, L., Hansson, H., Tusubira, F. F., \& Danielson, M. (2008). Exploring the E-learning State of Art. The Electronic Journal of e-Learning, 6, 2, 77-88.

[37] Turner, C., \& Turner, K. D. (2017). The Effects of Educational Delivery Methods on Knowledge Retention. Journal of Education for Business, 92, 5, 201-209. https://doi.org/ $\underline{10.1080 / 08832323.2017 .1331989}$

[38] Haverila, M., \& Barkhi, R. (2009). The Influence of Experience, Ability and Interest on ELearning Effectiveness. European Journal of Open, Distance and E-Learning, 1-13.

[39] Hrastinski, S. (2008). A Study of Asynchronous and Synchronous E-Learning Methods Discovered that Each Supports Different Purposes. Educause Quarterly, 4, 51-55.

[40] Karmakar A., \& Nath, A. (2014). E-learning Methodologies, Strategies and Tools to Implement Lifetime Education Anywhere Anytime. International Journal of Innovative Research in Advanced Engineering, 1, 4, 193-201.

[41] Bower, M., Dalgarno, B., Kennedy, G. E., Lee, M. J. W., \& Kenney, J. (2015). Design and Implementation Factors in Blended Synchronous Learning Environments: Outcomes from a Cross-Case Analysis. Computers \& Education, 1, 86, 1-17. https://doi.org/10.1016/ j.compedu.2015.03.006

[42] Chin, C. (2020). Learning Mustn't Stop with Covid-19. The Star. https://www.thestar.com.my/news/education/2020/03/29/learning-mustnt-stop-with-covid19 
[43] De Fazio, T., Ketonen, J., \& Crock, M. (2012). Quality Assurance in a Consortium: Open Universities Australia, in Jung, I., \& Latchem, C. (Eds), Quality Assurance and Accreditation in Distance Education and e-Learning: Models, Policies and Research, Routledge, New York, NY, 124-129. https://doi.org/10.4324/9780203834497

[44] Idrus, N. (2006). Quality Assurance in ODL. Proceedings of the 6th SEAAIR Conference, OUM, Kuala Lumpur, pp. 284-291.

[45] Kumari. S. (2012). Factors Affecting Students' Retention and Attrition in the Open and Distance Learning System. Indian Journal of Open Learning, 21, 1, 19-40.

[46] Zabidi, N. A., Woo, T. K., Kumar, P. R., Fadzil, M., \& Husain, S. H. S. (2017). Quality Assurance in Learning Material Development at OUM. Asian Association of Open Universities Journal, 12, 1, 69-81. https://doi.org/10.1108/aaouj-01-2017-0014

[47] Hattie, J. A. C., \& Donoghue, G. M. (2016). Learning Strategies: A Synthesis and Conceptual Model. Science of Learning, 1, 16013, 1-13.

[48] Venkatesh, V., \& Bala, H. (2008). Technology Acceptance Model 3 and a Research Agenda on Interventions. Decision Sciences, 39, 2, 273-315. https://doi.org/10.1111/j.15405915.2008.00192.x

[49] Ndubisi, N. O., \& Jantan, M. (2003). Evaluating IS Usage in Malaysian Small and Mediumsized Firms Using the Technology Acceptance Model. Logistics Information Management, 16, 6, 440-450. https://doi.org/10.1108/09576050310503411

[50] King, W. R., \& He, J. (2006). A Meta-Analysis of the Technology Acceptance Model. Information and Management, 43, 6, 740-755. https://doi.org/10.1016/j.im.2006.05.003

[51] Ozturk, A. B., Bilgihan, A., Nusair, K., \& Okumus, F. (2016). What Keeps the Mobile Hotel Booking Users Loyal? Investigating the Roles of Self-Efficacy, Compatibility, Perceived Ease of Use, and Perceived Convenience. International Journal of Information Management, 36, 6, 1350-359. https://doi.org/10.1016/j.ijinfomgt.2016.04.005

[52] Bruner, G. C., \& Kumar, A. (2005). Explaining Consumer Acceptance of Handheld Internet Devices. Journal of Business Research, 58, 5, 553-558. https://doi.org/10.1016/ j.jbusres.2003.08.002

[53] Ramirez-Anormaliza, R., Sabate, F., \& Llinas-Audet, X. (2016). The Acceptance and Use of the E-Learning Systems among the University Teachers in Ecuador. The $8^{\text {th }}$ Annual International Conference on Education and New Learning Technologies, July 6 2016, Barcelona, Spain. https://doi.org/10.21125/edulearn.2016.1836

[54] Tabak, F., \& Nguyen, N. T. (2013). Technology Acceptance and Performance in Online Learning Environments: Impact of Self-Regulation. MERLOT Journal of Online Learning and Teaching, 9, 1, 116-130.

[55] Pham, L., Limbu, Y. B., Bui, T. K., Nguyen, H. T., \& Pham, H. T. (2019). Does E-learning Service Quality Influence E-Learning Student Satisfaction and Loyalty? Evidence from Vietnam. International Journal of Educational Technology in Higher Education, 16, 7, 1-26. https://doi.org/10.1186/s41239-019-0136-3

[56] Tabachnick, B. G., Fidell, L. S., \& Ullman, J. B. (2007). Using Multivariate Statistics. Boston: Pearson.

[57] Kim, H. (2013). Statistical Notes for Clinical Researchers: Assessing Normal Distribution (2) Using Skewness and Kurtosis. Restorative Dentistry \& Endodontics, 38, 1, 52-54. https://doi.org/10.5395/rde.2013.38.1.52

[58] Malhotra, N. K. (2012). Basic Marketing Research: Integration of Social Media. Boston: Pearson Education. 


\section{Authors}

Dr. Thoo Ai Chin obtained her PhD in Supply Chain Management from Universiti Teknologi Malaysia. She is a senior lecturer and Head of Program for Bachelor of Management (Marketing) in Azman Hashim International Business School, Universiti Teknologi Malaysia. Before beginning her career in academic world, she was a material planner in Flextronics Technology (M) Sdn Bhd for 2 years. Further, she pursued her career in Philips Electronics Singapore as Supply Chain Officer for another 2 years. Her passions include student development, consultation, teaching, publications and community engagement works. She actively involves in research and publications pertaining to supply chain management, green supply chain management, logistics and green logistics, marketing, consumer behavior, entrepreneurship and customer relationship management.

Dr. Hang See Pheng is a senior lecturer in the Department of Mathematical Sciences, Faculty of Science, Universiti Teknologi Malaysia. She obtained her PhD in Computer Science from Universiti Teknologi Malaysia. Her research interests include machine learning for medical image analysis and mathematical modeling. She also involves in teaching mathematics and statistics for undergraduate courses, postgraduate supervision and community services related to STEM in schools.

Dr. Lee Yoke Lai is a Senior Lecturer and Postgraduate Research Coordinator of Landscape Architecture Program. She started her academic career as a tutor since 2009 in Faculty of Built Environment, Universiti Teknologi Malaysia (UTM). She graduated from Department of Urban Engineering, Graduate School at The University of Tokyo, Japan in 2016. She joined the Territorial Design Studies Unit (Kubota-sensei Lab) and Urban Design Laboratory (Nishimura-sensei Lab) during her PhD studies at The University of Tokyo. She received her Diploma in Architecture (2002) from Polytechnic Sultan Haji Ahmad Shah, Kuantan, Pahang; BA Hons in Landscape Architecture (2008) and Master SC in Urban Design (2012) from Universiti Teknologi Malaysia (UTM). Her current research interest is urban studies, cultural landscape, urban conservation, urban history and social history, as well as landscape design.

Sr Dr. Tan Liat Choon currently is a senior lecturer at the Department of Geoinformation, Faculty of Built Environment and Surveying, Universiti Teknologi Malaysia (UTM), Skudai, Johor in Malaysia. He received his Certificated in Land Survey from Politeknik Kuching Sarawak, Malaysia, Diploma in Land Survey from Universiti Teknologi Malaysia (UTM), Degree in Land Survey from UTM and Master in Land Administration and Development from UTM. In $12^{\text {th }}$ December 2012, he received his $\mathrm{PhD}$ from UTM for his thesis on "Towards Developing a Three-Dimensional Cadastre for Three-Dimensional Property Rights in Malaysia". His research interests focus on 3D property and Land Administration and expertise in Cadastre, Land Survey, Land Law and Survey Regulation, Stratified Property (Strata) Management, Stratified Property (Strata) Development, Land Administration \& Development, Land Registration and Land Information System. Sr Dr. Tan Liat Choon formerly is an Assistant Director of Survey at Department of Survey and Mapping Malaysia (JUPEM) since 16th July 2003. He was first attached as Assistant Director with Malaysian Centre for Geospatial Data Infrastructure (MaCGDI).

Article submitted 2021-05-12. Resubmitted 2021-06-23. Final acceptance 2021-06-24. Final version published as submitted by the authors. 